\title{
The predicaments of child victims of crime seeking justice in Ethiopia: a double victimization by the justice process
}

\author{
Getachew Assefa Woldemariam
}

Faculty of Law, Addis Ababa University, Ethiopia

\begin{abstract}
This article presents an account of a legal system that has fundamentally failed Ethiopia's young and vulnerable citizens. The Ethiopian justice process has permitted the subjection of child victims to cycles of traumatisation during investigation, prosecution and trial phases of cases in which they are involved. Ethiopia does not have laws that require the special treatment of children who are victims or witnesses of crime. It has neither rules of criminal procedure nor evidence that direct the conduct of criminal proceedings involving child victims. This article will show that although the Ethiopian Constitution incorporates principies such as the consideration of 'the best interests of the child', the realization of this principle for the Ethiopian child victim of crime remains illusory due to the absence of detailed rules that guide and compel the justice process to that effect. Based on empirical data, the article argues further that although ad hoc initiatives to introduce victims to a child-friendly justice process exist in a limited number of urban areas, these initiatives do not reach the vast majority of child victims around the country who continue to be further victimized by the justice process.
\end{abstract}

Key words: Ethiopia, child victims, justice process, court, double victimization

\section{Introduction}

A legal system cannot be complete unless its substantive, procedural and evidentiary rules are capable of addressing, as far as possible, all the identified problems of the members of its society. It is an affront to justice to see that while there is a clear picture of the problems, there is no measure taken to solve them. In Ethiopia, the case of the complete absence of laws governing the process of justice in relation to child victims catches one's attention for just this reason. Today no one wants to be in the position of an Ethiopian judge, prosecutor or police officer to handle a case in which a child victim is involved. This is because she knows that, owing to the absence of a law that directs and guides the proceedings before her, the child victim will be doubly victimized as the latter will be subjected to procedures that are in place for adults. 
The Ethiopian Constitution devotes a full article to the rights of a child. The Constitutional provision embraces, among other things, the principle of the consideration of 'the best interests of the child' in all actions concerning children undertaken by public as well as private bodies (Ethiopian Constitution, 1995, Art. 36). Ethiopia has ratified the UN Convention on the Rights of the Child, and the African Charter on the Rights and Welfare of the Child. It is one of the countries that debated and adopted the Universal Declaration of Human Rights in 1948 and it is also an active participant in the formulation of international standards in the field of children's rights. In spite of these positive attributes, the realization of the principle of the best interests of the child and the rights in the conventions for the Ethiopian child victim of crime remains elusive.

Studies have established that child victimization mars a child's mental and psychological wellbeing and development. It has been documented that, among others, child victims of crime continue to suffer from feelings of suspicion, stigma, betrayal, and powerlessness for the rest of their lives. Importantly, the traumatisation suffered by child victims as a result of an insensitive justice process perpetuates these feelings. It is disturbing that such a situation is allowed to continue in our society when with some effort the cycle of traumatisation in the justice process could be stopped.

Unfortunately, as we speak, most of the child victims in Ethiopia undergo this double victimization at the hands of justice personnel during their involvement in the justice process. This article is a modest attempt to show the suffering of Ethiopian child victims as a result of their experiences in the criminal justice system. The article limits itself to what happens to child victims in the formal justice process at the levels of crime detection and investigation, prosecution and trial. Because of its limited scope, the child protection aspects of the problem such as separation of child victims from an abusive family, provision of social services (counselling, and post-justice process services to the child victim) are not considered here as they merit fuller treatment elsewhere. In order to put in place a theoretical and international context, the article includes a conceptual discussion of the effects, on a child, of child victimization. A discussion of the international legal standards of the protection of child victims will provide a useful frame within which to view the Ethiopian legal system.

The article discusses both the legal and practical aspects of treatment of child victims in the Ethiopian justice process. For this purpose, the relevant laws will be assessed. For its practical aspect, the article primarily uses a 2007 study conducted under the auspices of the African Child Policy Forum (hereafter ACPF study or the study) on the treatment of child victims by the criminal justice system in Ethiopia. This author was one of the two lead-researchers who undertook the study. The Study was conducted in Addis Ababa and seven other major Ethiopian urban areas and their vicinities.

The seven urban areas are located in three of Ethiopia's regional states, namely, Amhara, Oromia, and the Southern Nations, Nationalities and Peoples States. The three states together account for about $65 \%$ of the country's total landmass and close to $90 \%$ of its population. The ACPF study has reached various informants through questionnaires, group discussions and interviews. The informants include parents, young boys and girls 
aged between eighteen and twenty five, police officers, prosecutors, judges, governmental and non-governmental organizations. A total of 222 youngsters aged between eighteen and twenty five participated in the study through structured interviews. The age bracket of these youngsters was necessitated by ethical considerations with regard to talking to children under eighteen years of age about such sensitive matters in a normal research setting.

The study also reached 215 parents, ror police officers, 46 prosecutors, and 37 judges through questionnaire and structured interviews. Furthermore, in-depth interviews were conducted with 5 judges, 7 prosecutors and ro police officers as key informants. About a dozen social workers participated in focused-group discussions while three were interviewed for the study. The author has also used his personal observations and experience as a source for the empirical aspect of the information in this article as he has been an active participant (including in the ACPF study in question) in both academic and practical issues discussed in the article for more than a decade. The sample population and the methods of data collection are believed to have generated credible first hand information regarding the participation of Ethiopian child victims of crime in the justice process.

So far, there has not been any comprehensive study undertaken directly on younger children for the above-mentioned ethical reasons, and possibly for other reasons as well. But, the findings of the ACPF study used by this author show directly the situation of child victims of crime, mostly young children. This is precisely because, first, the questions that were put to the youngsters mentioned above were carefully designed to draw out information regarding the victimization of them, their friends, relatives or neighbours during their childhood, i.e., when they were under 18 years of age. This was done in such a way that they would be able to tell the story of the victimization they knew of that was committed upon children rather than adults. Second, the discussions and interviews that were made in the study with the police, prosecutors, judges and other functionaries involved in the justice process centred primarily on the predicament of child victims, not on adult victims. Therefore, the findings of the study are presented with confidence as being relevant to the actual cases of young children facing the traumatizing experiences in the justice process.

This article looks primarily at the suffering of sexually abused female children. This is because of the paucity of reports of cases involving the abuse of male children in Ethiopia. This, however, should not be taken to mean that there are no cases of sexual abuse of male children for studies have shown that the sexual abuse of male children in Ethiopia is on the rise. A recent study conducted in Addis Ababa on street male children revealed that $28.6 \%$ of them were sexually abused (Getnet Tadele, 2009: 174 ). This same study has also indicated that sporadic studies conducted in some selected areas of the country show that sexual victimization of male children is widespread in many parts of the country, albeit on different scales (Id.). It is sad to note, however, that cases dealing with the sexual abuse of boys have not yet started to come through the justice process in large numbers due to the taboo surrounding all aspects of homosexuality in the country. It was observed during the ACPF study that cases of sexual abuse involving 
boys have in some cases been reported to the police but were not committed to prosecution and trial.

Although the main focus of this article is on the process of justice in relation to female child victims, its findings can be extended on a general level to the treatment, within the justice system, of sexual abuse cases involving boys. The arguments advanced in this article maintain that Ethiopia's legal regime and its existing practices do not take into account the particular vulnerability of child victims and witnesses, both boys and girls. It needs to be emphasised that the stories told and documented in this article in relation to the treatment by the justice process of female child victims are applicable to all male children as well.

\section{Definition of a Child and a Child Victim}

International and regional child rights instruments define who a child is based on age. Article I of The Convention on the Rights of the Child (CRC, I989), defines a child as "every human being below the age of eighteen years unless under the law applicable to the child, majority is attained earlier". The definition of the African Charter on the Rights and Welfare of the Child (ACRWC, 1990) is more definitive and states that "a child means every human being below the age of eighteen years".

In terms of the notion of a child victim, international treaty law does not give us a clear interpretation of its meaning. However, inferences can be made from some provisions in the universal and regional instruments about acts that can be considered broadly as acts of child victimization. An important provision, in this regard, is Art. Ig of the CRC which stipulates that states parties have the obligation to protect the child from all forms of physical or mental violence, injury or abuse, neglect or negligent treatment, maltreatment or exploitation, including sexual abuse. A similar reference to acts of child abuse and the concomitant responsibility on the states parties is made under Art. 16 of ACRWC.

According to the UN Economic and Social Council's Guidelines on Justice for Child Victims and Witnesses of Crime (2004), a child victim is a child and adolescent under the age of 18 , who is a victim of crime regardless of his/her role in the offence or in the prosecution of the alleged offender or groups of offenders. Here, the sort of narrower definition of a child given in CRC has been done away with by firmly defining a person of below eighteen years of age as a child. Furthermore, it is interesting to note that the Guidelines consider a child as a victim of crime regardless of his or her taking part in the offense, or the prosecution of a given criminal act. 
It is appropriate to see further how 'victimhood' is characterized as a legal concept for the purpose of protection. Although no international instrument directly addresses what is meant by the 'victimhood' of a child, a good definition that addresses child and non-child victims is found in the UN General Assembly Declaration of the Basic Principles of Justice for victims of Crime and Abuse of Power (A/RES/40/34, 1985). According to this Declaration:

'victims' means persons who, individually or collectively, have suffered harm, including physical or mental injury, emotional suffering, economic loss or substantial impairment of their fundamental rights, through acts or omissions that are in violation of criminal laws operative within Member States, including those laws proscribing criminal abuse of power (Paragraph One).

The Declaration further stipulates that a person may be considered a victim regardless of whether the perpetrator is identified, apprehended, prosecuted or convicted and also regardless of the familial relationship between the perpetrator and the victim. The term "victim" also includes, where appropriate, the immediate family or dependants of the direct victim and persons who have suffered harm from intervening to assist victims in distress or to prevent victimization (Id., Paragraph Three). Three interesting features stand out from the above two definitions. The first is the appropriate broadness of the definition of 'victimhood' which includes the whole spectrum of physical, mental or emotional suffering. The second point worth noting is that for the purpose of protection, 'victimhood' does not depend on, among other things, whether or not the perpetrator has been convicted. The third interesting point is the inclusion of the immediate family and dependents of the victim in the definition.

Turning to the domestic laws of Ethiopia, we see, first of all, that there is no clear definition of a child. Nor is there a definition of a child victim under the domestic laws of Ethiopia. The Constitution, for example, simply states the rights accruing to a child without defining who a child is (see Art. 36). Other laws of Ethiopia set forth a functional definition for the purpose of civil law. Accordingly, a person of less than eighteen years of age is considered as a minor (Revised Family Code, 2000, Art. 25I). As will be later shown, the Ethiopian criminal laws also treat persons of less than eighteen years of age differently both for the purpose of substantive protection and for increasing the penalties on the perpetrators of crimes against children, giving the impression that the legislature considers persons of less than eighteen years of age as children.

\section{Effects of Faulty Criminal Justice Process on the Child Victim}

Studies have long since established that acts of child victimization leave lasting mental and psychological scars that affect the well being and development of the child. For example, in relation to sexual abuse, Finkelhor suggested four areas of long-term effects that sexually abused children would live with (cited in Westcott and Page, 2002: 137). These are in the areas of sexualisation (in which the abused child will remain confused about sexual identity and become suspicious of any future sexual association and intimacy); stigmatization (where the abused child will continue to harbour feelings of guilt, 
shame, low self esteem and indifference); betrayal (where the child feels grief, depression, hostility, and an impaired ability to judge the trustworthiness of others); and powerlessness (where the victim child develops anxiety, fear, lowered sense of efficacy, and perception of helplessness) (Id., P. 140; Kippenberg, 2009; Callamard, 1999: 26). There would also be other social and emotional consequences that have far reaching negative effects. Female victims of sexual violence may face ostracism; a high possibility of permanently dropping out of school; difficulty in finding a partner; and/or the prospect of divorce. These and other social rejections would in turn lead to severe economic and social problems, loss of self-esteem or a turning to prostitution (Callamard, 1999: 27). Nor are the medical and physical effects of child victimization to be underestimated. The more clearly established medical effects of sexual abuse, for example, include sexually transmitted diseases (including HIV/AIDS), stomach pains, nausea, vaginal pains, generalized pains, infertility, miscarriage, stillbirth, and unwanted pregnancy (Callamard, 1999: 23).

What is more disturbing is the fact that, unless extreme care is taken, the justice process into which child victims are brought (after falling victims to criminal acts) does have an effect of repeating and elongating the pain and suffering of the child victims. This is so not only because the justice process brings back the traumatizing memory to the child victim but also because s/he fears retaliation by the perpetrator; being sent to jail; being punished for making a mistake describing the details of the offense(s) in front of strangers; and not understanding the questions being asked (Kippenberg, 2009).

The criminal justice system in its traditional sense is meant to protect the defendant and not the victim as such. This is the philosophy of a criminal justice system which normally considers that in criminal proceedings, it is the defendant, not the plaintiff (which happens to be the state in lieu of the people) that needs protection (Watkins, I990, P. 35). As such, therefore, the rule against self-incrimination, the right to confront a witness against oneself, the right to have a defence lawyer, the right to a fair hearing, the right to a speedy trial, etc... are all designed to protect the defendant. This philosophy utterly fails to take into account the position of child victims who are involved in the justice process. The insensitivity to child victims and witnesses in a criminal justice process largely continues in most legal systems in the world although there are certain measures being taken following the positivist interpretation of the rights of the child under international law as will be discussed in the following section of this article. It is therefore fair to say that child victims and witnesses of crime face traumatisation on a daily basis as they come into contact with the justice process. Child victims will be subjected to repeat questioning from preliminary investigation to the time of trial (Bulkley, 1981: 10; cited in Watkins, 1990: 36). They will be interviewed by different officers, seeking the same information, leading to undue repetition. Watkins quotes Bukley reporting a statement by a law enforcement official that 'a child sexual abuse victim may be required to repeat her story as many as $14-16$ times before going to court' (Watkins, 1990: 36).

Although repeated questioning is by itself a matter of serious concern, as it undoubtedly delays the healing process of a victimized child, the environment in which the whole matter, including the questioning, is handled compounds the traumatisation 
of the child victim. The inevitable exposure of the child's privacy to the neighbourhood and to the wider community exacerbates the child's feeling of stigma and helplessness. The language to be used by all those who are involved in the process of questioning the child victim can again perpetuate the traumatisation. For one thing, complex language may make it difficult for children to understand and therefore properly bring out what they know about the incident being investigated (see Korkman et al., 2008). In this regard, many scientific studies have shown beyond doubt that complex questions can be confusing and even absolutely meaningless for children (see for example Hutcheson, et al., 1995; Perry, et al., 1995; Walker, 1993). Moreover, strong and inconsiderate language (for example, in a cross-examination setting) may make the child victim feel shameful, anxious, guilty, etc. Studies have vividly shown that cross-examinations in which victim children are portrayed as 'unchildlike', 'wicked liar', and 'instigators' of the crime have the effect of perpetuating the traumatisation of the child no less than the act of victimization itself (Westcott and Page, 2002: 140).

This author has personally observed, in 2007, a rape case in which an Ethiopian judge acquitted the rapist by characterizing the rape victim child as an instigator-accusing her as a 'child' belonging to generations of youngsters that 'carry 'fire' in their armpits', an aphorism he used to depict her as un-childlike and culpable. The effect of this judicial behaviour on that particular child would be devastating.

It is worth noting that the predicament of child victims in the justice process is not only a reflection of general societal attitudes towards children but also a consequence of these attitudes. Some such damaging attitudes include untrustworthiness, suggestibility, poor memory, and the assumption that children do not distinguish between fantasy and reality. However, across various studies, it has been shown that children are not disposed to these negative traits any more than adults and in fact these studies show that children almost never make willful and malicious allegations (Finkelhor et al., 2005: 90; Brennen, 1994: 55-64). Untruthful child witnesses are comparatively uncommon (Brennen, 1994: $71)$. But society has refused to accept that children as a class of people make no worse witness than adults. At the same time, we must be mindful of the fact that as children, they have different levels of metacognitive development which calls for a special treatment commensurate with their level of development (see Perry, et al., 1995). It is precisely the child's lack of understanding that contributes to his or her misery in the justice process.

On a related note, delays in the justice process have often been seen to lead both to lapses of memory of the child victim regarding the particulars of the victimization, and the lack of interest both in the victim child and in her parents/guardians. 
When the criminal process drags on or is delayed, parents and victims may lose interest in the matter. They may want to end the process altogether by retracting the accusation. Watkins rightly points out that:

Retraction is viewed differently by the child, the clinician and the criminal justice system. Retraction, for the child, means an end to the painful process of interviews and court appearances. Clinicians generally view retraction as a sign that the child needs emotional support. The criminal justice system assumes retraction is evidence of $a$ false allegation and will most likely lead to an acquittal (Watkins, 1990: 36).

The ACPF (2007) study has documented a befitting behaviour from the above three actors in an extraordinary rape case. In this case, the trial opened six months after its reporting; two infants of three and five years of age, who were raped by the same person, were subpoenaed to appear before the court as witnesses. The mother of these child victims protested the subpoena, on account that the two children, especially the older one, had developed a serious psychological disorder, including difficulty to sleep at night. The mortified mother said that she suffered a lot and was finally able to help her children get over the trauma, and that their testifying now before the court would revive the pain and trauma. However, the judge was not willing to accept this genuine plea, and he continued to insist that the child victims testify before the court. After waiting a couple of adjournments, he gave an order that the police arrest the children and bring them before the court.

A very disturbed mother went to the Children's Legal Protection Centre of ACPF and obtained advice to take the victims to a psychiatrist for examination for post traumatic stress syndrome. The psychiatrist examined them and wrote a testimony to the court that they were not in a position to undergo a process that brings back the memory of victimization and forces them to relive it. As a result, the court closed the file and released the accused saying that the latter had no case to answer.

It has become clear that the traditional criminal justice process was not designed with the particular vulnerabilities of child victims of crime in mind. As alluded to earlier, there is now a general positive tendency towards making the justice process more child victim sensitive. For example in the United States, the video-taping of intense interviews with child victims of sexual abuse have been accepted by several states to be used at the various levels of the trial (Watkins, I990: 39). Increasingly, states have introduced statutes that allow the creation of a special hearsay exception for videotaped statements of child victims of sexual abuse in order to permit the prosecution to offer them as evidence that the child was abused (Eatman, I986, cited in Watkins, I990: 39). CCTV has also been allowed by many states in the United States to broadcast a child's testimony into the court room (see also Wilson, 1989). There is also an encouraging development in international child rights law in which attention is increasingly given to the all-round promotion and protection of child rights. In relation to child victims of crime, an encouraging development is the special attention being paid to the matter in international 'soft' law which will be discussed in the following section. 


\section{International Legal Standards of Treatment of Child Victims of Crime by the Criminal Justice System}

The need for children to be protected against all forms of abuse and exploitation because of their vulnerability and immaturity first appeared in the 1924 League of Nations Declaration of the Rights of the Child (International Association Of Prosecutors Model Guidelines, I999). Subsequently, the United Nations Universal Declaration of Human Rights, adopted in 1948 , proclaimed that childhood is entitled to special care and assistance (Art. 25). The United Nations Declaration of the Rights of the Child (1959) further stipulated the need to extend particular care to the child. More specifically, the adoption of the United Nations Convention on the Rights of the Child in 1989 brought into being a clear statement of the rights of and special treatment for the child.

The preamble of the Convention on the Rights of the Child forcefully states that the child, by reason of his or her physical and mental immaturity, needs special safeguards and care, including appropriate legal protection. The Convention also states that in all actions concerning children, the best interests of the child shall be a primary consideration. Particularly, the CRC obliges member states:

to take all appropriate legislative, administrative, social and educational measures to protect the child from all forms of physical or mental violence, injury or abuse, neglect or negligent treatment, maltreatment or exploitation, including sexual abuse, while in the care of parent(s), legal guardian(s) or any other person who has the care of the child (Art. 19).

The CRC adopts a rights-based approach to the treatment of children setting out four general principles that should guide all types of protection, support and assistance to children: non-discrimination; upholding the best interests of the child; the right to life, survival and development; and the respect for the views of the child. The Convention recognizes the child as a full human being, possessing integrity and personality and with the ability to participate fully in society. In treaty form and widely ratified, the standards contained in the Convention are binding and universal. While most provisions affirm human rights standards already recognized in other international human rights instruments, the Convention is a binding instrument specifically intended to define the basic rights of children. The Convention calls for the promotion of physical and psychological recovery and social rehabilitation of children who have been victims of any form of neglect, exploitation or abuse.

Furthermore the African child's rights are to be protected by the ACRWC which has come up with some interesting particularities different from the $\mathrm{CRC}$. For example, the ACRWC (Art. 20) has included detailed responsibilities of parents towards children while the CRC does not. Another departure is that it has a specific provision, unlike the CRC, on providing special attention to children who are living with their convicted mothers (Art. 30).

More specific principles on the need for special treatment of child victims are contained in various declarations and Guidelines primarily at the UN level. The UN Guide- 
lines for Action on Children in the Criminal Justice System is one of the earlier such soft law instruments which require that any measure established to treat child victims should ensure that they are treated with compassion and respect for their dignity. It further stresses that 'states should undertake to ensure that child victims and witnesses of crime are provided with appropriate access to justice and fair treatment; restitution; compensation; and social assistance' (Guidelines For Action On Children In The Criminal Justice System, 1997, paragraph 43). These Guidelines further stipulate that justice personnel (judges, police, prosecutors, advocates, and others) should be given training in handling cases that involve children as victims; states should establish specialized offices and units to deal with cases involving offenses towards children; and, importantly, that codes of conduct and practice for proper management of cases involving child victims be developed (Id., Paragraph 44). States are also required, by these Guidelines, to put in place judicial and administrative mechanisms to enable child victims to obtain prompt, fair and accessible redress, including restitution and/or compensation for losses sustained. States are further required to evaluate, review and improve their evidentiary and procedural rules to, among other things, avoid direct contact between the child victim and the offender; prohibit the identification of the child in the media, in keeping with other fundamental laws; enable the use of videotaped testimony of the child victim as an official piece of evidence in court proceedings; and require justice personnel to use more child friendly practices in the conduct of their official duties (Id., Paragraphs 47-50).

These UN Guidelines also call upon states to increase the responsiveness of judicial and administrative processes to the needs of child victims by informing the child victims about the whole process of their case, including their role in the case; encouraging the development of child witness preparation schemes prior to their giving evidence; and allowing the views and concerns of child victims to be presented and considered at appropriate stages of the justice process.

The above principles and requirements have been more forcefully and comprehensively stated in later Guidelines by the Resolution of UN Economic and Social Council - 'Guidelines on Justice for Child Victims and Witnesses of Crime' - referred to above. They emphasise numerous areas of importance, summarized earlier, including the child victim's right to be protected from hardship during the justice process in which, for example, justice personnel (professionals) are called upon to limit the number of interviews with the child victim, to integrate their services under one roof, and to use a modified court environment (Guidelines On Justice For Child Victims And Witnesses Of Crime, 2004, Paragraphs 30-32).

The Rome Statute of International Criminal Court (ICC) has taken international treaty law a step forward by providing for specific provisions on the protection of victims and witnesses of crime who participate in the justice process. The Statute declares that the Court shall take appropriate measures to protect the safety, physical and psychological well-being, dignity and privacy of victims and witnesses by having regard to all relevant factors, including age, gender and health, and the nature of the crime, particularly where the crime involves sexual or gender violence or violence against children. Moreover, the 
Statute directs that Prosecutors shall take similar measures of protection particularly during the investigation and prosecution of such crimes (Art. 86(I)). The Statute also makes an express exception on the principle of public trial on account of protecting victims and witnesses, and calls for the possibility to conduct of any part of the proceedings in camera or to allow the presentation of evidence by electronic or other special means. The Statute again states that such measures shall be implemented in particular in the case of a victim of sexual violence or a child who is a victim of or witness to a crime. The obligation to consider the views and concerns of the victims at appropriate stages of the proceedings, and the obligation to give assistance and protection to victims and witnesses have been placed on the courts and the prosecution in the ICC Statute (Art. 68(2,3)).

In a similar fashion, the protection schemes put in place in the ICC Statute have been implemented in the Sierra Leone Special Court. This court was created in 2002 as a national-international court by agreement between the Sierra Leonean government and the United Nations to prosecute serious crimes committed during the Sierra Leone war (199I-200I) (Howarth, 2009: 400). The Court established a Victims and Witness Support Unit that implemented measures for the physical and emotional protection of victims and witnesses as part of the overall judicial process (Kippenberg, 2009). Victims and witnesses were accorded temporary places of accommodation before and after testifying. Their identities were withheld, and they testified via CCTV with the use of voice-distortion mechanisms (Id.). But even in Sierra Leone, this kind of favourable treatment does not reflect the situation in the regular justice process in that country. In the regular justice process in Sierra Leone, child victims are subjected to a slow, tardy and insensitive justice process (National Child Justice Strategy for Sierra Leone, 2006). The justice system does not afford them any special treatment recommended by international standards some of which have been successfully implemented by the UN Special Tribunal for Sierra Leone, discussed above.

The situation of child victims and witnesses of crime in other parts of Africa also remains bleak, although there have been some improvements over the last ten years or so. As the discussion in the subsequent section shows, due to the overall influence of the international efforts to improve the conditions of child victims participating in the justice process, domestic legal systems in Africa have also, albeit slowly, shown some responsiveness. South Africa enacted a Children's Act in 2005 (Children's Act, No. 38, 2005). This Act deals comprehensively with matters of concern to children including the paramount importance of the best interests of the child, child participation in decision making, separate children's courts, evidentiary matters and other court proceedings involving children. South Africa had earlier, in 1998, taken two policy measures, known as National Policy Guidelines for Victims of Sexual Offences (enacted under the auspices of the Department of Justice and Constitutional Development), and National Guidelines for Prosecutors in Sexual Offence Cases (enacted by the Department of Justice). These Guidelines provide for detailed measures that should be taken by the concerned bodies in their dealings with cases involving child victims and witnesses of crime (Handbook for Professionals and Policymakers on Justice in Matters involving Child Victims and Witnesses of Crime, 2009: 7I-72). 
The Kenyan Sexual Offences Act, although meant only to deal with sexual offenses, has come up with child victim friendly rules to protect child victims participating in the justice process. It has for example made provisions for in camera proceedings, restrictions on publishing the identity of the victims, and the use of intermediaries to assist young children in giving evidence in courts. (The Sexual Offences Act No. 3 of 2006; Joint Report on the Workshop on Medico-Legal Responses to Sexual Violence, 2008). The Law also carries provisions that aim make police procedures easier for child victims, and to facilitate the provision of medical services for victims of rape and sexual assault (Njoki Ndungu, 2008). The medical examinations would also be used as evidence later in the prosecution of the offender thereby avoiding the difficulties surrounding medical examination of victims, such as the lapse of time between victimization and examination, and the qualification of the medical examiner - both of which were hitherto reasons for rejecting medical evidence or otherwise rendering it unhelpful.

Despite the above, and possibly other, improvements, the situation of child victims and witnesses of crime in Africa is still believed to deserve further serious attention. Even in systems such as that of South Africa, which was one of the first African jurisdictions where child-friendly efforts were taken, it was reported that dedicated services have recently declined in number, and alarmingly, in $86 \%$ of the country's courts, child victims of sexual assault have to confront their abusers face to face. Services such as CCTV, child intermediaries, witness rooms, etc, have been dysfunctional even where they were originally put in place (Karyn Maughan, 2008). Similarly, a very recent study on Uganda paints a sombre picture of the justice system in that country as regards their treatment of abused children, and women in general. It details a situation in which, from the beginning of the investigation process to the judicial trial of cases, a child victim is subjected to multiple levels of traumatisation thereby prolonging the initial abuse (Amnesty International, 2010). It is clear to see from these cases that African legal systems are not yet serious about removing the double victimization of child victims who come forward to seek justice. As shall be shown in full later in this article, the Ethiopian way of handling cases of child victims resembles in many ways those of other African states exemplified above.

\section{The Laws of Ethiopia Pertaining to Treatment of Child Victims of Crime}

The fact that the present Ethiopian Federal Constitution has clearly incorporated one of the CRC's basic principles which is the principle of 'the best interests of the child' is a step forward towards the protection and promotion of child rights. By virtue of its restatement in the Constitution, this principle has been elevated to be a constitutional rule. This would be advantageous to promoting and protecting the best interests of the child in relation to all government organs of the country whose decisions, actions and laws are required to yield to the Constitution.

The Ethiopian Criminal Code of 2004 and the Criminal Procedure Code of 196 I contain detailed provisions with respect to juvenile delinquents and their handling. Furthermore, the Criminal Code has criminalized a wide range of actions and omissions of culpability pertaining to children and attached to the crimes harsh punishments. The acts 
criminalized in the Code include sexual abuse, trafficking, infanticide, endangering the life of the unborn or the new born and failure in upbringing (See Criminal Code, 2004, Arts. 596-599; 626-628; 635-36). However, child abuse and victimization grounds such as child labour have not been criminalized. Verbal abuse, which studies show has a negative impact in the development of the child, has also not been considered in this Code. Interestingly, the Code decriminalizes 'the taking, by parents or other persons having similar responsibilities, of a disciplinary measure that does not contravene the law, for purposes of proper upbringing' (Arts. 68 and 576).

The ubiquitous failure of Ethiopian laws only begins to surface when one looks at the procedural and evidentiary laws pertaining to the justice process involving child victims. Ethiopia does not have a law of evidence proper, let alone one to deal specifically with child victims. This is a mammoth legal gap about which nothing has been done. The existing Criminal Procedure Code (196I) which guides the criminal justice process does not provide for even a single rule pertaining to child victims. In keeping with the philosophy of criminal justice process discussed earlier in this article, its emphasis was on the rights of the accused and not on a child victim facing the accused. This Code, for example, provides for an elaborate procedure as to how a juvenile delinquent should be treated in the justice process (See Criminal Procedure Code, 196I, Arts. 17I-80). Dramatic and emotionally wrought, situations were documented in the ACPF study used in this article. For example, when juvenile delinquents were accused of sexually abusing other children, the former were represented by an attorney (because the law requires this) while the child victims were made to face the situation all by themselves because the law does not require a lawyer to be appointed for a child victim.

\section{The Practice of Treatment of Child Victims by the Justice System in Ethiopia}

As the above summery of the Ethiopian law is believed to show, child victims are not within the protective compass of the procedural and evidentiary laws of Ethiopia. This clearly leaves the justice personnel with neither legal authority nor legal obligation to fashion the justice process in a child victim friendly way. In what follows, we will see a number of cases and practices from the Ethiopian justice process in order to get the sense of the ordeal of Ethiopian child victims as they take part in the justice process.

\section{The Case with the Police}

Obviously, the police are the first important formal point of contact with a child victim seeking justice. The police undertake works in relation to detection of the crime and an investigation which may involve several meetings with the child victim. Over the last decade, an interesting initiative has been taken first by a local NGO called Forum for Street Children Ethiopia (FSC) to establish Child Protection Units (CPUs) in police stations of select few urban areas of the country. Ideally, CPUs would function with a social worker and a police officer as their staffers. The ACPF study found out that CPUs were found in very limited urban areas but were non-existent in rural areas. Even in the areas where they were found, they functioned under severe resource constraints with often no social workers, or social workers 
barely trained in child handling techniques. Most disturbing of all however is that CPUs were part of a project by the FSC and were, therefore, fully dependent on the financing and project interests of the FSC. There was no guarantee about their sustainability. In spite of these drawbacks, however, in those places where they were functional, the ACPF study found out that the CPUs made positive contributions towards improving the handling of child victims at the investigation level. This was attested to by the youngsters and parents as well as the justice personnel who participated in the ACPF study.

Nevertheless, there remain considerable problems regarding the treatment of child victims during crime detection and investigation. It has already been mentioned that the scale of CPUs in Ethiopia were a drop in the ocean being present in only a handful of urban areas, and this in a country where eighty six percent of the population lives in rural areas. In a legal system where there is no requirement or direction as to how the detection and investigation of a crime involving child victims should be carried out, an Ethiopian victim child would experience the following treatment on a daily basis:

i. Failure to respect the privacy of the child victim during interviewing and investigation. A large number of the police informants reached by the ACPF study declared that they interviewed a child victim who came to their office in the presence of their colleagues ranging from two to five in number. The privacy of the child victim also suffered because all of the CPUs ,where they existed, were located in the premises of the police stations.

ii. Interviewing the child victim in an intimidating and fear-instilling atmosphere. The police officers in CPUs, and in all other cases where CPUs were not found, were required to interview the victim child in a very formal way and in uniform. This was noted to create a situation of fear for the child victim exposing the latter to emotional injury.

iii. Failure to take into account the views of the child victim regarding the progress and conduct of his or her case. The study revealed that a child victim and his/ her parents were not consulted in any meaningful way during the conduct of the case, nor was regular feedback given to the child victim and her/his parents by the investigating police officer.

iv. Failure to treat cases of crime against children in a speedy way any differently from other cases. It was found that, although there have been improvements over the last few years, especially where CPUs were up and running, the police would treat all cases of investigation in the same manner, and the fact that a case involves a crime against a child would not merit a speedy dispatch.

v. Maintaining similar or higher evidentiary threshold for cases involving crimes against children. Though the police does not have a direct role in proving the guilt of the perpetrator, the mind set of looking for the most comprehensive evidence in cases of child victims has contributed to the delay of the completion of the investigation process or the total rejection of the case. 
vi. The practice of not treating child victims of more than fifteen years as a child. The police would not consider a child of more than 15 years of age as falling within the definition of a child. This means that children within the age range of 15-18 do not benefit from the treatment of CPUs, and generally from the protections of the CRC and ACRWC.

These practices which the study found to be prevalent with the Ethiopian police conform to neither the CRC and ACRWC rules nor other standards recommended by the UN discussed earlier in this article which include the protection of the child's right to privacy; the right of the child to have her/his views taken into account in the decisions affecting him/her; provision of flexible evidence submission and admission systems, and observing for all children under 18 years of age the rights and protection guaranteed under the CRC, ACRWC and other international standards.

\section{The Case with the Prosecution}

The ACPF study has revealed that Ethiopian prosecutors in most cases would become involved in a case of a child victim only after the police officer in charge completed his/her investigation and formally submitted the investigation file. The study also revealed that prosecutors normally saw child victims for the first time in courts during the trial or hearing of the cases.

Another problem related to the treatment of child victims in the hands of prosecutors concerns the absence of cooperation and coordination among the justice organs and other related institutions. This in fact was not only the problem of the prosecution, but also of other justice organs and once again of the law of the country that does not provide for such a requirement. Other problems of treatment of child victims during the prosecutor's case preparation, which fly in the face of the international standards, include:

i. Absence of a practice of witness preparation. This situation is contrary to the internationally recommended standards such as the ones laid down by the International Association of Prosecutors and the 2004 UN Guidelines. These Guidelines require prosecutors to explain the role of the victim as a witness and explore her/ his ability and willingness to testify in court.

ii. Failure to adequately take into account the views and concerns of the child victim and her families. The international guidelines and standards on the prosecution of crimes against children oblige the prosecutors to review with the victim the strengths and weaknesses of the case, procedural considerations (preliminary hearings, motions, trial, sentencing, etc.), time, sequence of events before, during and after the assault. The Study has revealed that the prosecutorial services have not met these standards.

iii. Insensitivity to the privacy of the child victim. It has been noted that prosecutors, as was the case with the police, did not take into account the need for privacy in their communication with the child and her parents. 
iv. Maintaining the same evidentiary threshold in cases of crimes against children as in other cases and not taking into account the age of the child in procedures and requirements of child testimony. The international standards require that the prosecutors should consider children as capable witnesses when they are able to credibly report events that have happened to them. In cases where the prosecutors think that the testimony of a given child witness is confused or is not sufficient for any reason they obtain the assistance of experts and expert testimonies. By doing so, it is required that prosecutors exercise great caution in deciding not to prosecute a crime against children. The study has shown that the Ethiopian prosecutor used the same evidentiary approach in weighing the prosecutability or otherwise of a crime involving child victims and those of adults. This problem is aggravated by the lack of law of evidence in the country, which the ACPF study has identified as a serious problem.

v. Non-existence of a practice of working in cooperation with other organs and institutions on processing and preparing the case of a child victim. The study revealed there was no practice of working together with other institutions and experts. The prosecutors would not make use of the community workers that function in the CPUs even where there were CPUs with appropriate staff. Also they would not make use of other experts such as psychologists and psychiatrists, even in cases of needy child victims that were involved in the process as witnesses. The study revealed that the absence of this practice was largely due to awareness problems on the part of the prosecutors, and also because of the absence of the law that required this practice.

vi. Absence of the practice of giving priority to cases of child victims. This problem was noted with regard to the police earlier. Though there has been an improvement over the past few years, there was no established system enshrined as a matter of principle with which the prosecution might give priority to cases of crimes involving children. Again, this problem has been explained as resulting from the lack of a clear law that requires the prosecution to prioritize cases of child victims.

vii. Failing to seriously engage in the case of a child victim and helping the child victim to testify without fear and tension during the trial stage of the case. The study also laid bare that prosecutors were very passive in the court process. Some of the judges who were interviewed in the study have stated that prosecutors often did not actively follow up cases and their dereliction of duty had a damaging effect on the fate of the cases of the child victims involved.

\section{The Case with the Judiciary}

The blame once again has to be placed on the non-existence of laws in Ethiopia which require a child friendly conduct of court proceedings. The silence of the law has been interpreted in practice as non-requirement and, thus, today the trial of cases involving child victims in almost all cases is undertaken in the same way as cases involving adults only. The ACPF study has found that in only two of its study areas (Addis Ababa 
and Bahir Dar cities) were there Child Victim Friendly Benches (CVFBs) designated in one of their first instance courts' branches. Given the information of this author, the findings of the study as to the non-existence of CVFBs could be extended to most, if not all, of other parts of the country. Therefore, cases involving child victims were, and still are, handled in ordinary courts. There is no specialized or at least no separate and convenient courtroom for seeing such cases.

Judges who participated in the study stated that they use their own discretion to decide how to undertake the trial of cases involving child victims. Most cases in which children of $15^{-18}$ years were involved as victims were considered to be cases of adults by courts, and were processed in a like manner to that of adult cases. So judges might decide to hold a closed hearing for a particular aspect of the case such as when the victim had to show part of her body as evidence. Even in this case, they would allow the defendant to be present in the courtroom. It was further clarified by the interviews with judges that the treatment of child victims between the ages of $\mathrm{I}_{3}$ and $\mathrm{I} 4$ was also dependent on the discretion of the individual judge, so the question of whether to follow the ordinary procedure or have an in camera hearing. In cases of child victims of less than 13 , in-camera hearings were generally ordered at the discretion of the judges. However, the court would allow the accused to be present during the proceeding whatever the age of the child victim. The following are additional practical problems of the treatment of child victims by the judiciary in Ethiopia:

i. Allowing the offender or his attorney to cross-examine the victim child in person. Judges would allow suspected offenders and/or their attorneys to cross-examine the victim child during trials. The judges that participated in the study had a very strong feeling about the right of the offender to cross-examine the child victim. At the same time, they showed little sensitivity to the misery of the child victims before them. But, as discussed earlier, internationally recommended standards require that alleged offenders should not be allowed to confront child victims during the process of the case.

ii. Granting of bail to alleged offenders with a small bond. The police, youngsters, parents and social workers who participated in the study all said that one of the most serious problems for dealing with crimes against children was the granting of bail. Once bail had been granted, the study documented, the accused either disappeared, changed residence or worked around the clock to tamper with evidence and/or intimidate the child victim who would be a key witness against him.

iii. Not welcoming and not according the necessary value to the testimony of child victims. Judges were generally found to be very suspicious about the reliability of child victim testimonies, and this usually worked in favour of the offenders who manipulated the situation. This mind-set of Ethiopian judges reflected the same problem in other jurisdictions as shown in the literature canvassed in this article. The judicial state of mind can be epitomized by a case documented in the ACPF study in which a female child was raped by an adult in 2006 and the case was 
referred to a local court in Northern Ethiopia's Dessie Town. The judge asked the girl how and where she was raped; the girl told the judge that she was raped on a bed. When the judge asked the same question to an eye-witness, the latter said the girl was raped apparently on a mattress. In his decision on the case, the judge stated that the testimonies given by the victim and the so called eye-witmess were contradictory calling into question their truthfulness, and, hence, it would be difficult to convict an accused on the basis of such "contradictory" testimonies, and promptly acquitted the accused.

iv. Not accepting other modes of receiving testimonies of child victims. Most of the judges who participated in the study were of the opinion that the testimonies of parents, nurses, teachers or social workers should not be accepted in lieu of a child who could not testify herself for different reasons. The main reason for this position was said to be the requirement in the law that the accused has the right to confront a witness testifying against her/him.

v. Not conducting any meaningful victim impact assessment before passing sentences in a given child victim case, and not soliciting the victim's opinion on the case. The study showed that courts did not consult the child victims and their families before passing their decisions on cases concerning them. They solely depended on the prosecutor, for example, regarding motions for bail and determination of the terms of the penalty.

vi. Not making use of professionals in undertaking assessment of the damage on the victim before making final determination on the case. Most of the judges indicated that except for medical experts (medical doctors or nurses), they never used other professionals as expert witnesses at any stage of the judicial process.

\section{Conclusion}

As pointed out earlier, although few initiatives by the government and non-governmental actors have begun to alleviate a fraction of the suffering of child victims seeking justice in Ethiopia, their predicament is still far from being ended because the efforts so far made are very limited and insignificant compared to the scale of need of child victims. The establishment of CPUs, CVFBs in a few places and courts as indicated earlier is a step in the right direction but needs to be extended to many more courts and police stations. The study has also indicated that some NGOs have been providing for support and assistance for children, including child victims. For example, the Children's Legal Protection Centre of the ACPF and the Ethiopian Women Lawyers Association - one of the pioneer civil society organizations - have provided legal advice and support for child victims of crime and their parents. These efforts are encouraging and have to be multiplied. Of late, however, the Ethiopian government's legal measure to restrict the involvement of civil society actors in the protection of rights may dampen their contribution in this regard (see Charities and Societies Proclamation No. 621/2009, Arts. I4 and 57).

It needs to be emphasized that the source of most of the problems of the treatment of child victims by the Ethiopian justice process is the gap in the law. As shown earlier, the laws entirely overlook the needs of child victims. Ethiopia is under an international 
obligation to reform its laws to bring them in line with the international treaty obligations such as the CRC and the ACRWC and to take measures, including legislative and administrative, to put in place child victim sensitive justice process. Ethiopia has to act now rather than later to utilize the guidelines provided by the international soft law instruments discussed in this article and improve the treatment of child victims. The author does not intend to outline detailed recommendations in this article (as this is not an action-oriented paper, but an academic one). It is, however, necessary to state that to end the suffering of child victims in the justice process requires a comprehensive set of measures that should include legal and administrative reforms; training of justice personnel; and building of appropriate court rooms, police stations and offices for prosecutors and other relevant staff. These measures require the allocation of resources to which the government must commit itself. While some of these measures should be taken in the long run, the government should in the short term embark on, for example, the pursuing of an active policy of training justice personnel to infuse them with the knowledge, attitudes and skills necessary to treat child victims appropriately. The government must also, in the short-term, pursue an active policy of ensuring the implementation by its justice personnel of the international standards discussed earlier in this article for improving the treatment of child victims. On the whole, only by taking seriously the measures indicated above, will Ethiopia ensure that child victimization ends with the first act of crime rather than continuing through the insensitivities of the justice process.

\section{Acknowledgements}

I thank my colleagues who have read the earlier version of this article and offered their valuable comments. I particularly thank Assistant Professor Mehari Redae and Mr. Tesfu Baraki who, along with myself, took part in the study sponsored by the African Child Policy Forum used in this article, and with whom I exchanged valuable ideas during the conduct of the study. I also thank the Forum for making the study available, and the editorial staff of Afrika Focus Journal for their comments and editorial assistance. Last but not least, I am profoundly grateful to the anonymous assessors who have given me constructive comments that have helped improve the quality of the article. The author is solely responsible for any remaining errors.

\section{References}

African Union (1990). African Charter on the Rights and Welfare of the Child.

African Child Policy Forum (2007). Treatment of Child Vittims by the Ethiopian Legal System. (Unpublished Report, on file with the author).

Amnesty International (2010). I cannot Afford Justice: Violence against Women in Uganda Continues. (Unchecked and Unpunished). Available at http://www.amnesty.org/en/library/asset/AFR59/0or/2010/en/ f3688aao-b771-464b-aa88-85obcbf5aI52/afr590012010en.pdf. Last access December 212010.

Brennean, Mark (1994). The Battie for Credibility - Themes in Cross Examination of Child Victim Witnesses. International Journal of the Semiotics of Law, v. 7, n. 19: 52-73. 
Charities and Societies Proclamation of Ethiopia (2009). No. 621.

Callamard, Agnès (1999). Rights and Democracy, Documenting Human Rights Violations by States Agents: Sexual Violence (Montreal: Rights and Democracy 1999): 23-27. Available at http://www.dd-rd.ca/sitel_ PDF/publications/women/StatesAgents.pdf. Last access September 10, 2010.

Finkelhor, Davide et al., (2005). The Justice System for Juvenile Victim: A Comprehensive Model of Case flow. Trauma, Violence, \& Abuse, v. 6, no. 2: 83-102.

Getnet, Tadele (2009). 'Unrecognized victims': Sexual abuse against male street children in Merkato area, Addis Ababa. Ethiop. J. Health Dev., vol. 23, no. 3: 174-182.

Howarth, Kathryn (2008). The Special Court for Sierra Leone - Fair Trials and Justice for the Accused and Victims. International Criminal Law Review, v. 8: 399-422.

Hutcheson, Graeme D. et al. (1995). Child witness statement Quality: Question Type and Errors of Omission. Law and Human Behaviour, v. 19, no. 6: 631-647.

International Association of Prosecutors (1999). Model Guidelines for the Effective Prosecution of Crimes Against Children. Available at http://www.icclr.law.ubc.ca/ModelG.rtf. Last access 18 September 2010.

Joint Report on the Workshop on Medico-Legal Responses to Sexual Violence, 2008. Available at http:// www.preventgbvafrica.org/system/files/MedicalLegalWorkshop_Nairobi.pdf. Nairobi, Kenya, Last access October 13, 2010.

Karyn, Maughan (2008). Justice system's devastating failure for child rape victims. (News) The Mercury (South Africa). Available at http://www.highbeam.com/doc/1 II-I82654340.htmlArticle. Last access 7 February 2011.

Kippenberg, Juliane (2009). Protecting Child Victims in Sexual Violence Trials in the DR Congo: Suggestions for the Way Forward. Available at http://www.hrw.org/en/news/2009/11/24/protecting-child-victims-sexual-violence-trials-dr-congo-suggestions-way-forward. Last access Io September 2010.

Korkman et al. (2008). Failing to keep it simple: Language use in child sexual abuse interviews with 3-8-year-old children. Psychology, Crime and Law, v. 14, no. 1: 41-60.

Njoki Ndungu (2008). Legislation for Sexual Violence in Africa: Preparing and Delivering Evidentiary Requirements. Available at http://www.svri.org/legislation.pdf. Last access II February 2011.

Perry, Nancy W. et al. (1995). When Lawyers Question Children: Is Justice Served? Law and Human Behaviour, v. 19, n. 6: 609-629.

Republic of South Africa, (2005). Act No. 38, Children's Act; Government Gazette, Vol. 492 Cape Town, 19 June 2006, No. 28944 .

Sierra Leone (2006). National Child Justice Strategy for Sierra Leone. Available at http://www.britishcouncil. org/national_child_justice_strategy.pdf. Last access ir February 2011.

The Constitution of the Federal Democratic Republic of Ethiopia, (1995).

The Criminal Code of Ethiopia (2004).

The Criminal Procedure Code of Ethiopia (I96r).

The Revised Family Code of Ethiopia (2000).

The Sexual Offences Act No. 3 of 2006 of Kenya.

United Nations, (1985). Declaration of Basic Principles of Justice for Victims of Crime and Abuse of Power UN Resolution. (A/RES/40/34).

United Nations (1998). Rome Statute of International Criminal Court. A/CONF.183/9.

- (1989). Convention on the Rights of the Child.

- (1997). Guidelines for Action on Children in the Criminal Justice System. Recommended by the UN Economic and Social council. (1997/30).

- (2004). Guidelines on Justice for Child Victims and Witnesses of Crime. Adopted by the UN Economic and Social council (2004/27).

- (1948). Universal Declaration of Human Rights. 
United Nations Office on Drugs and Crime (2011). Handbook for Professionals and policymakers on Justice in matters involving child victims and witnesses of crime. Available at http: $/ / w w w . u n o d c . o r g / d o c u m e n t s / j u s-$ tice-and-prison-reform/hb_justice_in_matters_professionals.pdf. Last access II February 20 II.

Walker, Anne Graffam (1993). Questioning Young Children in Court: A Linguistic Case study. Law and Human Behaviour, v. 17, no. I: 59-8I.

Watkins, Sallie Ann (I990). The Double Victim: The Sexually Abused Child and the Judicial System. Child and Adolescent Social Work, v. 7, no. I: 29-42.

Westcott, Helen L. and Page, M. (2002). Cross Examination, Sexual Abuse and Child Witness Identity. Child Abuse Review, v. Ir: 137-152.

Wilson, C. E. (1988-1989). Criminal Procedure-presumed Guilty: The use of Videotaped and closed circuit televised testimony in child sexual abuse prosecutions and the defendants right to confrontation - Coy V. Iowa. Campbell Law Review, v. Ir: 38I-396. 